\title{
Polygamy Permits for Business Reasons (Analysis of Sawahlunto Religious Court Ruling Number: 045/Pdt.G/2018/ PA.SWL)
}

\author{
Zainal Azwar', Firdaus², Anshari Az-Zarqy ${ }^{3}$
}

${ }_{1}^{1}$ State Islamic University Imam Bonjol

e-mail: zainalazwar@uinib.ac.id

${ }^{2}$ State Islamic University Imam Bonjol

e-mail: firdaus@uinib.ac.id

${ }^{3}$ Supreme Court of the Republic of Indonesia

e-mail: ari.azzarqy@gmail.com

\begin{tabular}{|l|l|l|}
\hline Received: 20-08-2021 & Revised: 31-10-2021 & Accepted: 10-11-2021 \\
\hline
\end{tabular}

Abstract: Under Law number 1 of 1974 article 4 and article 57 compilation of Islamic law, polygamy can be permitted for several reasons (conditions); The wife does not carry out duties as a wife, there are bodily defects or diseases that cannot be cured, and cannot bear offspring. In contrast, the judge at the Sawablunto Religious Court granted the polygamy permit application on business grounds. The questions that will be answered in this article are; First, what is the consideration of the $S$ aw a hlunto Religious Courtjudge granting the application for polygamy permit on business grounds? Second, what is the decision of the Sawablunto Religious Court on polygamy permits on business grounds when viewed from the opinion of jurists? This research is categorized as a field research, used interview and documentation as the techniques in gathering the data. This paper concludes: first, the consideration in granting the application because there is a written permission given by the wives, the husbands are able to be fair, the permission brings prosperity and benefit to husbands wives and children beside building the houselod integrity and the future of their business. Second, the second Religion Court Decision number 045 / Pdt.G/2018/ Pa.Swl. The Fiqih Scholars open up the oppertinity of polygamy practice for other reasons that switch to the social context and needs, a fairness as the main requirement.

Abstrak: Dalam pasal 4 UU No 1 Tahun 1974 dan pasal 57 Kompilasi Hukum Islam, poligami dapat dibolehkan karena beberapa alasan (syarat); Istri tidak menjalankan kewajiban sebagai istri, ada cacat badan atau penyakit yang tidak dapat disembuhkan, dan tidak dapat melahirkan keturunan. Sebaliknya, hakim Pengadilan Agama (PA) Sawahlunto mengabulkan permohonan izin poligami dengan alasan bisnis. Pertanyaan yang akan dijawab dalam artikel ini adalah; Pertama, apa pertimbangan hakim PA Sawahlunto mengabulkan permohonan izin poligami dengan alasan bisnis? Kedua, bagaimana putusan PA Sawahlunto tentang izin poligami dengan alasan bisnis jika dilihat dari pendapat para ahli hukum? Penelitian ini penelitian lapangan, data dikumpulkan melalui wawancara dan dokumentasi. Penelitian ini menemukan bahwa pertama, pertimbangan dalam mengabulkan permohonan karena ada izin tertulis yang diberikan oleh istri, suami mampu berlaku adil, izin membawa kesejahteraan dan kemaslahatan bagi suami istri dan anak-anak disamping membangun keutuhan rumah tangga dan masa depan dari bisnis mereka. Kedua, Putusan PA kedua nomor 045/Pdt.G/2018/Pa.Swl. Ulama Fiqih membuka peluang praktik poligami dengan alasan lain yang beralih ke konteks sosial dan kebutuhan.

Keywords: Polygamy, business, Religious Court

\section{INTRODUCTION}

$\mathcal{T}_{\text {he Qur'an and Hadith do not strictly }}$ regulate the reasons and reasons for polygamy unless it is permissible to marry up to four women as long as it can be fair. Fairness in question includes the affairs of 
residence, living, clothing, and all things that are born. Why is it only those who are born? For Allah has made sure in his word in Surah al-Nisấ verse 129, that you cannot be fair among your wives, even if you are eager to do so. (Ghazali, 2013: 129).

As Surah al-Nisâ' verse 129 is interpreted in Mukhtashar Tafsir Ibnu Katsir, that the slightest human being will not be able to be fair on all sides. Although everything has been done by birth, it is like division in the night. But inwardly, related to sex, love, and intercourse will certainly experience differences and different judgments from couples (Shakir, 2018: 315). Thus, polygamy has a very tight and heavy opportunity to do. It is said to be strict because in nash principle rules and state laws provide very strict odds. While it is said to be heavy because of the fair conditions required by the nash. Once the requirements are according to state rules in the form of there must be permission from the first wife.

In Indonesia, polygamy is not prohibited. It's just that it takes the right rules, procedures, and reasons to do it. Polygamy should not be done indiscriminately so that women's rights can be maintained and protected. In this case, the Government sets out the polygamous procedures and conditions contained in the positive law. One of them is mentioned in article 40 of Government Regulation No. 9 of 1975, "if a husband intends to marry more than one, then the husband is obliged to apply in writing to the court". In the sense of the judge's permission for polygamy. The verdict and supervision of the judge are pseudo because it could be that the judge does not know the true cause (actually). Usually, everyone must hide everything from others which is the privacy of their home life. (Az-Zuhaily, t.th: 6675).

The Court may permit if there are determining reasons or conditions, as mentioned in article 4 of Law number 1 of 1974 jo $57 \mathrm{KHI}$, namely the wife does not carry out duties as a wife, the wife has a body defect or disease that cannot be cured, or the wife cannot give birth to offspring.

In contrast to the above-mentioned regulations, the judge at the Sawahlunto Religious Court granted polygamy permission to a man for business reasons as stated in the verdict number: 045/Pdt.G/2018/Pa.Swl. Basically, in the ruling, it is not explicitly mentioned polygamy permits for business reasons but rather because of work affairs. The job in question is a business venture. The verdict of the sitting section of the case mentioned, that the husband owns a business and company in The Country of Malaysia. The husband only has the opportunity to return home together once in three months. The husband is also afraid of far-flung conditions and rarely comes home will do an act that is not cold. The husband does not want to divorce his wife.

In addition, the wife also could not be invited to Malaysia, because after weighing several reasons, it did not allow her to leave the wife's parents and children who were also in education. To find another solution, before the husband decided to be polygamous, the husband had attempted to find a job not far from the shared residence. However, let alone the work that produces the earned, so the cost of living is increasingly uncontrolled spending.

In short, the husband decided to marry a Malaysian woman who is also the husband's co-worker (applicant) in 
Malaysia. If the husband is not married to the Malaysian woman, then the husband cannot work and develop the husband's business in Malaysia. Because previously the husband had gotten some problems that resulted in the husband often getting a ban every time he entered the country of Malaysia. Thus, after going through some conjugal deliberation, the wife permitted the husband to remarry evidenced by a statement of the wife willing to be drunk. Later in the trial, the judge handed down the verdict and permitted the husband to be polygamous.

Based on the background above, the formulation of the problem is; The decision of the Sawahlunto Religious Court Judge who gave polygamy permission to a man for business reasons has come out of the provisions of the legislation but has the opportunity to be accommodated in the provisions of nash al-Quran and hadith. questions that will be answered in this article; 1 ). What is the consideration of the sawahlunto religious court judge granting the application for a polygamy permit on business grounds?; 2). What is the decision of the Sawahlunto Religious Court on polygamy permits on business grounds when viewed from the opinion of jurists?

The study of polygamy is nothing new. There's been a lot of previous writing about this. Among them, the writing of Slamet Firdaus (2012) with the title Poligami Bagi yang Mampu, Monogami Bagi yang Tidak Mampu. This article discusses the comparison of polygamy and monogamy in order to reach the sakinah family. Sakinah is obtained not based on polygamy or monogamy, but how or how to develop mawaddah and rahmah. In the end, there is a need for mutual tolerance between the pros and cons of polygamy and monogamy.
(Firdaus, 2012). While the article written by Ismail Marzuki with the title Politik Hukum Poligami: Studi Terhadap Peraturan Perundang-Undangan di Negara-Negara Muslim, concluded that although in the books of polygamy jurisprudent is something that is allowed, in practice each Islamic country has a different legal policy related to polygamy, namely: (1) Some allow polygamy, (2) some allow polygamy with strict conditions, (3) some prohibit polygamy. In addition, this article also discusses the "merits" of legal politics on polygamy from the school of jurisprudent which is majority embraced in each Islamic country. (Marzuki, 2019). Atik Wartini (2013), wrote an article entitled Poligami: dari Fiqh hingga Perundangn-Undangan. This paper focuses on the study of legislation, the study of fiqh, as well as hadith, and the views of some contemporary scholars related to the issue of polygamy. This paper discusses sharply the view of normative rules related to polygamy in Indonesia which is full of pros and cons and with normative rules how to resolve it. (Wartini, 2013). Furthermore, the article was written by Khairil Anwar and Sri Ikamulia with the title Perkara Izin Poligami di Pengadilan Agama Bengkalis (analisis terhadap putusan hakim nomor: 0307/pdt.g/2017/pa.bkls). This article concludes that the decision of Judge PA Bengkalis who granted the application for polygamy permission was sole to protect the sociological and psychological aspects of the prospective second wife of the applicant and to realize the legal certainty of the relationship of both because the second wife already pregnant (Anwar \& Ikamulia, 2019). Another article, Ijtihad Hakim Pengadilan Agama pada Perkara Poligami written by Ashabul Fadhli and 
Fathur Rahmi. This paper concludes that judges in the Religious Court can conduct their own ijtihad by sticking to the jurisprudies and laws and regulations in deciding polygamy permit cases. In fact, sometimes judges can exercise contra legem rights. (Fadhli \& Rahmi, 2020)

Some of the articles mentioned above, in general, do talk about polygamy. But none discussed specifically polygamy permits for business reasons. Therefore, this paper deserves to be considered as a study that presents new information that has never been revealed before.

\section{RESEARCH METHODS}

This type of research is field research using a normative legal approach. Data is collected directly to the research site (Sawahlunto Religious Court). The data collection technique was conducted through interviews with judges who tried polygamy application cases in case number: 045/Pdt.G/2018/Pa. Swl at the Sawahlunto Religious Court and documentation studies of the judge's ruling on polygamy permit application cases for business reasons, namely verdict number:

045/Pdt.G/2018/Pa.Swl. Therefore, the primary data source in this study is the Judge of the Sawahlunto Religious Court and his Ruling related to the case. While the secondary data sources of this study are books and other reading materials that are relevant to this study. The study also used tertiary sources in the form of dictionaries and encyclopedias. The data that has been collected is analyzed using content analysis techniques.

\section{RESULT AND DISCUSSION}

Theory of Polygamy
Polygamy is a word that has been liberated into Indonesian which is also derived from the English language, namely polygamy (married to more than one person) (Echols and Shadily, 1976: 437). But presumably, the meaning of polygamy itself cannot be fully accommodated because it generalizes the husband or wife has more than one partner. Whereas in Islam, polygamy is an allotment for husbands who have more than one partner. According to Arabic, polygamy comes from two words, ta'addud which means to be numerate (more than one), and al-Zawjat, which means wives (plural form). So, Ta'addud alZawjat means married more than a woman or many (polygamy) (Munawwir, 1984: 904). According to the Great Dictionary of Indonesian, the marriage system that one party owns or marries several opposite sexes at the same time (Author's Team, 2005). The meanings of polygamy according to $\mathrm{KBBI}$ is also considered inappropriate because it seems not to distinguish between polygamy and polyandry. While the term polyandry comes from the English namely polyandry (called polyandry) (Echols and Shadily, 1976: 438). Simply put polyandry means being married more than a man (Munawwir, 1984: 904). Polygamy is a man who has more wives than a woman, while polyandry is a married woman than a man (Mahyuddin, 2003: 59-40). Polygamy is a Shari'ah that has been enshrined in the Qur'an surah al-Nisấ verse 3 .

Syekh Musthafâ al-Marâghi in his commentary mention, the ability to be polygamous as mentioned in the word of Allah SWT in surah al-Nisâ' verse 3, is complicated and tightened ability. Polygamy is allowed only in emergencies, which can only be done by people in need, 
and must be recorded for the sake of prudence in polygamy (Al-Maraghi, 1963: 181). The most important thing in polygamy is the earnestness of polygamists to be fair, both in birth and inwardly. (Rofiq, 2015: 139-140)

The spirit of polygamy carried out by the Prophet Muhammad SAW (peace be upon him) is not because he obeys passions alone but has a noble mission that is in the framework of the development of da'wah and uplifting the dignity and dignity of women. It is evident, of the many wives of the Prophet (peace be upon him), only Aisha r.a. is a virgin. The rest were old widows except Hafsah bint Umar bin Khattab who was a young widow (who was 20 years old). (Summa, 2005: 179-180)

The marriage law in Indonesia adheres to the principle of monogamy (Tutik, 2007: 71). All the conditions relating to polygamy are explained in articles 3 paragraphs 1 and 2, and other matters concerning polygamy are mentioned in articles 4 paragraphs 1 and 2, and articles 5 paragraphs 1 and 2 (Sudarsono, 1991: 289). However, some argue that the principle embraced by Indonesian marriage law is not the principle of absolute monogamy, but the principle of open monogamy / not absolute. Polygamy is placed in emergency law, or extraordinary circumstances (Nuruddin \& Tarigan, 2006: 162). According to Zainuddin Ali, the reason for polygamy's ability refers to the purpose of marriage, which is to form a happy and eternal household (mawaddah, rahmah, and sakinah) based on the Supreme Divinity. That is, if the three reasons mentioned in the laws and regulations befall the husband and wife then it is strongly suspected that their household will not be able to give birth to happiness (mawaddah and rahmah). (Ali, 2006: 47)

For the purpose of such marriage to be realized in polygamous marriages, the judges in the Religious Court must carefully examine; the existence or absence of reasons that allow a husband to remarry, the presence or absence of consent from the wife, whether or not the consent is oral or written consent (if the consent is oral consent, consent must be uttered before a court hearing), the presence or absence of the husband's ability to guarantee the living needs of the wives and children, and the presence or absence of assurance that the husband will be fair to his wives and children with statements or promises. of the husband made in the form set for it.

With the strict examination and granting of polygamy permits as stated in the above laws and regulations, there has been effort and prudence of the government in protecting the rights of women and children. Including also reflecting that polygamy is not prohibited but complicated licensing.

\section{Reasons polygamy perspective of Jurispruded scholars}

\section{According to the Ulama Mazhab}

According to Hanafi, as quoted by As-Shahir Manla, that Polygamy is a permissible ruler on the condition that it can be fair. If a person is unable to be fair by providing shelter, birth, and inner living, then the ability of polygamy becomes illegal to do. It can be polygamous if it can be fair. Fair definition according to Hanafiah is to give rights in accordance with its portion. If his wife is rich, then his livelihood cannot be equated with the poor (Manlâ, t.th: 532). Thus, the Hanafi school does not specify in detail the reasons for polygamy but only allows 
polygamy on the condition that it can be fair.

According to the Shafi'i school, as quoted by Mustafa al-Khin, polygamy can be done because the wife is sick or infertile on the condition that the husband can be fair (born and inward) (Al-khindi, 1992: 36-39). Similar to the Hanafi school, the Shafi'i school is also not explained in detail about the reasons for polygamy. The ability of polygamy in this school also refers to whether or not the husband is able to act fairly.

The Hanbali school, in principle, prioritizes monogamous marriage, if the husband is unable to be fair. The school also does not mention in detail the reasons for polygamy. Polygamy can be done when the husband has high sex and feels uncomfortable with one wife. Monogamous marriage is considered better and more important than polygamy. (Fauzan, 2012: 324)

Not much different from before, the Maliki school asserts that the ability of polygamy is strongly related to fair conditions. Justice in question also includes the rights of wives in terms of division. According to the Hadith narrated by Abu David. "If a man has two wives, and he is more inclined to one of them, then on the Day of Resurrection he will come in a state of one of them tilted." (Al-Qurthuby, 2004: 78). That is, the Maliki school also does not elaborate on the reasons for polygamy except to only provide limits on fair conditions for polygamists as strengthened by hadith.

Based on the description above, it can be affirmed that among the scholars of the school, the ability of polygamy must be associated with the ability to be fair to the perpetrator. As for the reason for polygamy, in general, more to conventional reasons such as barren wives, husbands have high sex and are unable to take care of them. Thus, among classical scholars, the reason for polygamy's abilities is very simple and seems very subjective as husbands have a high shahwat.

\section{Contemporary Scholars}

According to Wahbah az-Zuhaily, polygamy is a rare and exceptions matter, which can only be done except under much-needed conditions. Sharia does not oblige anyone to even encourage it. However, sharia allows it for various general and special reasons (Az-Zuhaily, t.th: 6670):

\section{1) General Causes}

Common causes include an imbalance in the number of women over men such as wars, as happened in Germany (after the first world war). (AzZuhaily, t.th: 6671). So, this condition is very necessary for the enactment of a polygamous system both socially and morally that contains maslahat and grace. As well as keeping women from the perversions and vices that make them exposed to dangerous diseases and protecting them in a quiet and comfortable household. Other common causes, such as the need for people to increase the number of people to wage war against the enemy or to help agricultural work, factories, and others. Also included in this common cause is the social need to get kinship and besanan relationships to spread Islamic da'wah. As happened to the Prophet Muhammad (peace be upon him) who married nine women to broadcast da'wah and to gain support for the religion of Allah. (AzZuhaily, t.th: 6670)

2) Special Causes

Among the special forms of causes allowed polygamy is 1). The sterility of 
the wife or the presence of disease, or her character is not in line with the character of the husband. 2). The magnitude of a man's hatred for his wife for a long time, causing constant strife and quarrels. Then polygamy can be done so that the marriage is still saved. 3). Increasing the sexual ability of the husband due to the wife can not provide satisfaction due to the factor of older age or others. Polygamy can save him from the evil of adultery. (Az-Zuhaily, t.th: 6672-6673)

According to Syed Ameer Ali (contemporary Islamic thinker), polygamy is an act that is used as a solution, if society demands a situation that requires it. For example, when the number of women is too many, polygamy can be applied as an outlet to break up the problem. In his book The Spirit of Islam chapter on the status of women in Islam, Syed Ameer Ali outlines his view that a polygamy is an act that depends largely on certain situations and conditions. It is not impossible, with the progress of the times and the advancement of thinking that humans will change the state of the world, and the need for polygamy is lost (Ali, 1922: 229). The polygamous behavior of the Prophet Muhammad SAW (peace be upon him) must be understood in the context of social and Islamic proselytizing demands at that time. It cannot be generalized and occurs in all places after the situation.

Sayyid Sâbiq explains the reason for polygamy. For the sake of evoking the Islamic treatise, $\mathrm{b}$ ). There are more women than men, c). A man's ability to have a family is greater than a woman's ability in the same way. d). barren wives or affected by chronic diseases that cannot be cured. e). Sometimes there are men whose physical and psychological fitness has high sexual desire, so one woman is not enough. (Sâbiq, 1977: 114-121)

According to Shâlih bin Fauzân (mufti of Saudi Arabia), among the causes of polygamy is because there are more women than men. So as to stem the resulting mudharat, among others: in conditions of war, long journeys, at least the number of men than women. (Fauzan, 2012: 323)

Consideration of Judge Sawahlunto Relogious Court Granting Polygamy Permit Application on Business Grounds

The reasons of the judge as contained in the polygamy permit ruling with the case number: 0045/Pdt.G/2018/Pa.Swl, can be granted through logical legal considerations and under the rules and regulations of applicable law because all procedures that must be carried out by the applicant have been fulfilled (cumulative conditions).

Based on the rules that have been unified in law No. 1 of 1974 jo Government Regulation No. 9 of 1975 mentioned earlier, the panel of judges should look first at other possibilities besides giving permission to the husband to polygamy, at least there is a solution other than polygamy. However, after looking at the legal facts in the trial, there is no other solution than polygamy for the sake of remaining intact the husband and wife household. The judges have offered the husband to work in Indonesia and/or invited his wife and children to accompany him to work in Malaysia. However, all possibilities were disproved with answers from the parties and witnesses in the trial.

The thing that becomes a booster for the judge to permit the polygamous husband is because the husband has qualified cumulatively. The respondent 
has given consent to the applicant to remarry a woman named (second wife-tobe) based on willingness, both written and verbal consent before the judge. Why does the wife (the respondent) allow the applicant when the respondent has no deficiencies as mentioned in alternative conditions (Law No. 1 of 1974 Article 4 jo Article $57 \mathrm{KHI})$. The reason the respondent allows the applicant is because the respondent believes in the applicant, that the applicant loves himself very much. The applicant succeeded in convincing the respondent to be able to act fairly as the affidavit can be fair. The applicant also has an inner birth ability in meeting the needs of the family and the applicant has expressed a willingness to take responsibility in fostering his household in the future. The applicant has an income in Malaysia of Rp. 10.000.000,to Rp. 15.000.000,-- In addition, the applicant has lived in Malaysia for a long time, so if the applicant does not work in Malaysia, it is difficult for the applicant in collecting a living for his family rather than working in Indonesia. While the Applicant cannot bring his wife and children to Malaysia due to the condition of the parents who require the presence of the respondent. In addition to children who are studying in Indonesia and need parental assistance.

Then strong consideration for the applicant to be polygamous is the reason the applicant to be able to return to work developing his company in Malaysia. Because previously, the applicant was banned from returning to Malaysia for several reasons including the applicant's problems with one of the company bosses in Malaysia which is not possible to mention in detail here, and a residence permit in a neighboring country for a long time. By marrying a Malaysian woman, the applicant can return there and live and live for a long time in Malaysia. Finally, the applicant decides to marry the applicant's friend who is a widow (second wife candidate) in Malaysia (Malaysian citizen) to meet the economic needs of the applicant and the respondent. As long as the applicant is unable to return to Malaysia, the applicant has difficulty in meeting household needs (Darmawan: 2019). This reason was revealed in the trial, but not contained in the judge's ruling. In addition, the distance of the applicant from the respondent (as long as the applicant is in Malaysia) also raises concerns for the applicant to get caught up in the act of maximal (adultery).

So, textually the applicant applying for a polygamy permit is for work reasons, which for his intention also contains the intention that the applicant also feels worried about getting caught up in the act of maximal or adultery. Because in the job the applicant has a female coworker with widow status who also has shares or capital in the printing and advertising business. It is seen from these reasons that it is seen that the judge granted permission for polygamy for work reasons that contextually feared the occurrence of the deed of maximal between the applicant and his future wife.

The evidence of the trial was revealed, ranging from the evidence of the letter to the evidence of witnesses. The testimony of witnesses confirms the respondent's testimony and is also in accordance with the reasons submitted by the applicant. By adding that it has advised to carefully consider the polygamy plan. The consideration of polygamy itself is strengthened by the petitioner that he does not want to get caught up in adultery, so that after the judge hears the statements of both 
witnesses to be better if the applicant is allowed. Also seeing no syar'i obstacles, and the future wife there was no blood relation (mahrom), then the judge granted the request.

Logically, if the applicant is not responsible and does not love the respondent anymore, it could be that the respondent married secretly another woman to facilitate his efforts and intentions. However, because the applicant still loves and is responsible for his family (his wife and children), so the applicant takes the path or process that is not easy (strict rules). The purpose of the applicant is for the sake of the happiness and integrity of his household. Between the applicant and the respondent, there is no agreement in writing that the applicant is fully responsible for the livelihood of the respondent and the children. That is because the respondent is sure that the applicant will not neglect his obligations in terms of living.

Polygamy based on jurisprudence is only determined through Qs. al-Nisâ': 3. It also becomes the basis for judges in giving consideration other than Law No. 1 of 1974 on Marriage and Compilation of Islamic Law. Polygamy is marrying more than one woman at a time that is limited to four women. Polygamy is allowed if it is fair. If you can't be fair, then just one (monogamy). Indeed, the husband states that it can be fair, but justice can only be proven after the husband is polygamous. The law is difficult to follow up the consequences of the husband are proven to be unfair. It is not possible by annulling the marriage or polygamy of the husband or in any other binding way.

With the development of the times, modern scholars including positive laws in Indonesia, provide rules or reasons about the acquisition of polygamy. The concept in law No. 1 of 1974 on marriage is monogamous marriage. However, it is not closed the possibility to be polygamous with cumulative terms and alternative terms.

The reason for allowing polygamy according to the law is still too narrow, so it's also good if polygamy is considered a permissible but complicated act. Based on the positive law mentioned above, the applicant does not directly meet the alternative conditions as mentioned in Article 4 paragraph 2 of Law No. 1 of 1974 concerning marriage jo Article $57 \mathrm{KHI}$, As it is: The court referred to in paragraph (1) of this article only permits a husband who will marry more than once if:

a. The wife cannot carry out her duties as a wife;

b. The wife has a body defect or disease that cannot be cured;

c. The wife cannot give birth to offspring.

Presumably from the above rules, the respondent can still carry out his obligations as the applicant's wife. It's just that because the departure of the applicant working to Malaysia has implications for the respondent cannot carry out his obligations to the applicant. However, this is not the will of the respondent. But on the condition and economic situation alone that causes the respondent can not carry out his obligations as the applicant's wife and the applicant also forgives him. Conversely, the applicant is certainly also unable to carry out obligations on nonmaterial aspects as a whole.

Furthermore, other alternative conditions, such as the respondent having a body defect or disease that cannot be cured and the respondent cannot provide offspring for the applicant. Both alternative conditions are disproved by the birth of a pair of children from the 
marriage of the applicant and the respondent. The respondent also did not have a body defect or illness and this has been proven in the trial. However, although alternative reasons do not directly correspond to the applicant's reasons, the court cannot dismiss the case as long as the case meets the provisions of absolute authority and relative authority. The court must accept the case. So the court needs to look at other terms and conditions and how to prove them in the trial.

There are three references for the judge in deciding the case. These references are legal values, as Gustav Radbruch put it, namely: First is certainty (Rechtssicherheit). What is meant by its certainty is a verdict based on formal provisions or applicable laws. The second is expediency (Zweckmassigkeit). It means that everything related to the judge's decision is seen from the aspect of maslahah against both sides. The third is justice (Gerechtigkeit). Justice is the primary goal of the state judicial body. Then the sense of fairness can be felt towards both parties who are litigating (Rahardjo, 2012: 45). Of the three references, the judge felt it was appropriate to permit the applicant to be polygamous. In addition to having qualified cumulatively, the strengthening lies in the benefit. According to the judge, although in the law there is no mention that one of the conditions allowed polygamy because the husband works in a relationship with the residence of the wife. However, the judge can see through the facts of the trial. Can the applicant be allowed to be polygamous or not? It turned out that in the trial it was revealed that in Indonesia the applicant found it difficult to fulfill his living obligations to his wife and children. In Indonesia, the applicant has no business and also can not try so maximally. The applicant has been in Malaysia for a long time and has also owned companies in the country as well the economy can live. In addition, the wife cannot be invited to Malaysia, because of the interests of parents and children. The respondent wants his children to be educated in Indonesia. (Rahardjo, 2012: 45)

While in Malaysia, the applicant will return to his shared residence (in Indonesia) once and three months. Psychologically, young men need sexual distribution especially those who already have wives. The applicant is worried about committing adultery if the sexual appetite is not channeled. While in Malaysia, the applicant has money and wealth that according to the judge, the applicant can pay women for the sake of channeling their sexual appetite. However, do not want to do so and for the sake of avoiding the deeds of the maxim, the applicant thinks it is better to be polygamous. The woman who will be married is a widow and the respondent also allows it, so it is okay according to the judge to be allowed.

According to the judge, the reason for allowing the Prophet to practice polygamy (especially widows) was aimed at saving widows. Only one of the Prophet's wives was a virgin when she was married, Aisha. So, the granting of such permission is due to several benefits, including:

1) Benefit to the family of the applicant and the respondent who can remain intact (not divorced) and get along well. The applicant wants to keep giving attention and a living to his wife and children. So it also does not give a burden to the respondent if left by the applicant. 
2) The good for the applicant himself to be avoided from the deeds of maxim (adultery). Considering the applicant has known closely with the future second wife. Feared by the closeness and familiarity can also plunge the applicant into the abyss of efficacy. (Darmawan, 2019)

Judges have sought to establish the principle of monogamous marriage by advising and providing ways or solutions other than polygamy. It has also been working on a solution so that the wife and children accompany the husband to Malaysia (workplace). However, of all the solutions and advice submitted by the judge, based on the facts of the trial, it was revealed that there was no other way or solution for the applicant's household other than polygamy. The judge cited Wahbah az-Zuhaily's opinion that it was better to give permission for polygamy than the integrity of a broken or damaged household. (Ghani, 2019)

Concerning the non-conformity of the reasons submitted by the applicant with the rule of law, the judge argued that the judge was not the mouthpiece of the law. Judges make decisions and settle cases, based on justice and truth. So, if some laws or rules do not regulate or do not answer existing problems, the judge can make a new law outside the provisions of the existing law as long as the legal ruling brings benefits and does not conflict with the principle of the applicable rules. (Hadi, 2019)

The rules in Article 4 of Law No. 1 of 1974 jo Article 57 KHI starting from the wife cannot carry out obligations to the husband, the wife has a body defect or chronic disease that cannot be cured until the barren wife cannot give offspring to her husband, are conditions under ordinary circumstances. In the trial the judge can dig or find a new law, it turns out there are other conditions for certain people who are allowed to be polygamous (casuistic). Must look at other aspects that support the ability to be polygamous, not only alternative, cumulative, or other aspects of the law, but can be from sociological, psychological, philosophical, or other aspects that have benefits for the applicant and the respondent. Therefore, the principles of truth and justice depart from the benefits mentioned earlier.

So, based on the judge's ruling on polygamy permission above, it does not mean that the judge violates the law or rules, but the judge can see new things that are not summarized and contained in the law. But it's only casuistic, that is, only for certain people. The hope is that there will be legal developments in this era for the unanswered of all the complaints of justice seekers, whether in the form of government regulations, jurisprudence, or other rules.

Review of the Opinion of Jurists on the Decision of the Sawahlunto Religious Court Number: 045/Pdt.G/2018/PA.SWL

If analyzed the decision of the Sawahlunto Religious Court number: 045 / Pdt.G / 2018 / Pa.Swl which granted the application for polygamy permit for business reasons based on the view of jurists, it can be said that the ruling does not conflict with the views of jurists. The scholars of the school (Hanafi, Maliki, Shafi'i, and Hanbali) do not give strict limits on the reasons for allowing a person to be polygamous. Shafi'i and Hanbali schools indeed allow polygamy for several reasons and reasons such as sick wives who have no hope of healing medically, barren wives, and husbands who have high speech, but some of these reasons are not absolute limits that cannot 
be changed because they are not based on the clarity nash.

Nevertheless, the scholars of the school agreed to say that the absolute requirement of polygamy is that the husband can be fair, both in birth and inwardly. They also agreed that being fair to wives with differences and advantages and disadvantages of each is very heavy and difficult to realize. In addition, the scholars of the school also reminded that polygamous marriage must be able to realize the noble purpose of marriage, namely sakinah, mawaddah, and rahmah. As found in surah al-Rûm verse 21: "And among His signs is that He created a partner for you of your kind, so that you can tend and feel calm in Him, and He makes among you a sense of love and compassion. Surely there are signs like this for those who think. (QS. AlRûm: 21)

Based on the above verse, if the polygamous marriage cannot creating sakinah, mawaddah, and rahmah, or even will bring destruction in the household; Whether the household is with the first wife or so on, polygamy is not allowed. So among the triggers for the realization of the purpose of polygamous marriage is the ability of the husband to be fair. Therefore, Allah almighty reminds if he cannot be fair then there is enough for him just have one wife; Don't be polygamous. Like QS. al-Nisâ' verse 3: “And if you fear that you will not be able to be fair to an orphaned woman (whenever you marry her), then marry the (other) woman you are happy with two, three, or four. But if you are afraid that you will not be able to be fair, then (marry) one, or a female servant that you have. This is closer so that you will not do evil." (QS. Al-Nisâ': 3)

The decision of the Sawahlunto Religious Court Judge is also in line with the opinions of contemporary jurists. As outlined earlier, contemporary jurists classify the causes and reasons that allowed polygamy to be common and special causes; Among them, the husband traveled far so that he was separated from his wife for a long time. The latter cause is more relevant to the consideration of the sawahlunto religious court judge in granting the application for a polygamy permit for business reasons. For more details, the following will be conveyed again the consideration of judge PA Sawahlunto, namely 1). Because there has been permission from the wife, both in writing and orally delivered directly before the judge. 2). My husband can do justice. The ability to be fair is also stated in writing and verbally before the panel of judges. In addition, to convince the judge, the applicant shows evidence of income per month. 3). Polygamy permits can bring benefits and benefits to husbands, wives, children, household integrity, and the future of business. The benefits for the husband in question include the husband can be spared from the creation of adultery because separated from the wife who is far away in Indonesia, in addition to remaining the husband of the first wife and the father of the children. That is, the whole household is maintained. This has fulfilled the demands of Allah SWT in surat al-Isra' verse 32: "And do not come near adultery; It is a heinous act, and a bad way." (QS. Al-Isra': 32)

This consideration is also in line with the hadith of the Prophet (peace be upon him);

\section{لا ضَرَرَ ولا ضِرارَ}

Means: "Neither can dharar, nor do dhirar." (Majah, t.th: 2340).

So is the rule of fikih;

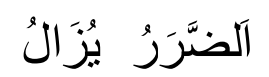


Means: "Losses are eliminated as much as possible." (Djazuli, 2005: 109)

In addition, among other benefits is the benefit of the future of the business. That is, by giving polygamy permission to the applicant, the person concerned will still be able to continue his business in neighboring Malaysia because he is married to a Malaysian woman as a condition of administration to develop the business and live for a long time in the country.

Based on the above description, it is clear that the consideration of the judge of the Sawahlunto Religious Court, although born out of the law, but in line with the principles of nash al-Quran and hadith of the Prophet (peace be upon him) and the opinions of jurists. In addition, this ruling also remains guided by the purpose of marriage, namely realizing sakinah, mawaddah, and rahmah. This reason can be considered as the result of the judge's ijtihad for the benefit of the seeker of justice by the times, the needs of the people, and the demands of the situation.

\section{CONCLUSION}

Based on the discussion in the previous chapters, it can be concluded: The consideration of the judge granting the application for a polygamy permit on business grounds is because there has been written permission from the wife, the husband can do justice, the polygamy permit can bring benefits and benefits for the husband, wife, children, household integrity, and the future of business. In addition, this reason is the result of the judge's ijtihad for the benefit of the seeker of justice.

The Sawahlunto Religious Court's ruling granting polygamy permission for business reasons does not conflict with the opinions of jurists, both classical and contemporary. This is because jurists do not give certain restrictions regarding the reasons for polygamy. Even impressed, jurists open opportunities for polygamy abilities for other reasons according to the social context and needs of the local community as long as fair conditions can be realized in polygamy.

\section{BIBLIOGRAPHY}

Ali, A. (1922). The Spirit of Islam: A Story of The Evolution and Ideals of Islam With a life of The Prophet. Delhi: Jayyad Press.

Ali, Z. (2006). Hukum Perdata Islam Di Indonesia. Jakarta: Sinar Gafika.

Djazuli. (2005). Ilmu Figh. Jakarta: Prenada Media.

Fauzân, S. (2012). Al-Mulakhas al-Fighy. Riyadh: Darul 'Âshimah.

Al-Khin, M. (1992). Al-Fiqhu al-Manhajî 'ala Mazhab al-Imâm asy-Syâfi'î.

Damaskus: Darul Qalam.

Majah, I. (2012). Shahih Ibn Majah. Jakarta: Pustaka Azzam.

Al-Marâghi, A. M. (1963). Tafsir alMarâghi. Mesir: Musthafa al-Baby alHalaby.

Mahyuddin. (2003). Masilul Fiqhiyah, Jakarta: Kalam Mulia.

Manlâ, A. (t.th.) Durar al-Hukkâm Syarh Gharar al-Hukkâm. t.t: Dâr Ihyâi alKutubi al-'arabiyyah.

Munawwir, A. W. (1984). Kamus Bahasa Arab-Indonesia. Surabaya: Pustaka Progressif. 


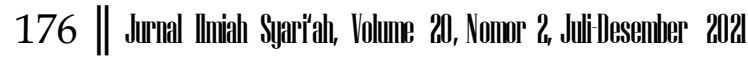

Nasution, H. (1992). Pembaharuan dalam Islam: Sejarah Pemikiran dan Gerakan. Jakarta: Bulan Bintang.

Nuruddin, A. \& Tarigan, A. A. (2006) Hukum Perdata Islam di Indonesia: Studi Kritis Perkembangan Hukum Islam dari Fikih, UU No 1/1974 Sampai KHI. Jakarta: Kencana.

Rusyd, I. (2004). Bidâyatul Mujtahidwa Nihâyah al-Muqtashid. Kairo: Darul Hadis.

Rofiq, A. (2015). Hukum Perdata Islam di Indonesia. Jakarta: Raja Grafindo Persada.

Sâlim, S. K. (2007). Fiqih Sunnah untuk Wanita. Jakarta: Al- I'tishom Cahaya Umat.

Sâbiq, S. (1977). Fiqih al-Sunnah. Beirut: Dârul Kitab al-'Araby.

Rahardjo, S. (2012). Ilmu Hukum. Bandung: Citra Aditya Bakti.

Soejono dan Abdurrahman. (1999). Metode Suatu Penelitian dan Penerapannya. Jakarta: Rinaka Cipta.

Soekanto, S. dan Mahmudji, S. (1985). Penelitian Hukum Normatif Suatu Tinjauan Singkat. Jakarta: CV Rajawali.

Sudarsono. (1991). Hukum Perkawinan Nasional. Jakarta: PT. Rineka Cipta.

Summa, M. A. (2005). Hukum Keluarga Islam di Dunia Islam. Jakarta: PT Raja Grafindo Persada.

Sunggono, B. (2003). Metode Penelitian Hukum, Jakarta: PT Raja Grafindo Persada.

Tutik, T. T. (2007). Poligami Perspektif Perikatan Nikah; Telaah Kontekstual Menurut Hukum Islam dan Undang-
Undang Perkawinan Nomor 1 Tahun 1974. Jakarta: Prestasi Pustaka.

Tihami dan Sahrani, S. (2010). Figh Munakahat: Kajian Fiqh Nikah Lengkap. Jakarta: PT. Raja Grafindo Persada.

Az-Zuhaily, W. (t.t.). Al-Figh al-Islâmy wa Adillatuhu. Damaskus: Darul Fikr.

Anwar, K., \& Ikamulia, S. (2019). PERKARA IZIN POLIGAMI DI PENGADILAN AGAMA BENGKALIS (Analisis Terhadap Putusan Hakim Nomor: 0307/Pdt.G/2017/PA.Bkls). JURIS (Jurnal Ilmiah Syariah), 18(2), 163. https://doi.org/10.31958/juris.v18i2 .1656

Fadhli, A., \& Rahmi, F. (2020). Ijtihad Hakim Pengadilan Agama Pada Perkara Poligami. JURIS (Jurnal Ilmiah Syariah), 19(2), 215. https:/ / doi.org/10.31958/juris.v19i2 .2429

Firdaus, S. (2012). Poligami bagi yang Mampu Monogami bagi yang Tidak Mampu. Al-Manahij: Jurnal Kajian Hukum Islam, 6(2), 269-286. https:/ / doi.org/https:/ / doi.org/10. 24090/mnh.v6i2.604

Marzuki, I. (2019). Politik Hukum Poligami (Studi terhadap Peraturan Perundang-Undangan di NegaraNegara Muslim). Al-Manahij: Jurnal Kajian Hukum Islam, 13(1), 141-157. https://doi.org/https:/ / doi.org/10. 24090/mnh.v13i1.1799

Wartini, A. (2013, December 15). POLIGAMI: DARI FIQH HINGGA PERUNDANG-

UNDANGAN. HUNAFA: Jurnal Studia Islamika, 10(2), 237-268. 


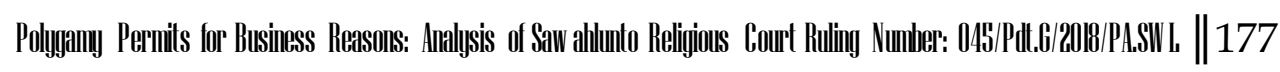
https:// doi.org/https:/ / doi.org/10. 24239/jsi.v10i2.29.237-268

Dermawan, Doni, (2019). Judge of Sawahlunto Religious Court, Interview, 02 Oktober.

Ghani, Armen, (2019). Judge of Sawahlunto Religious Court, Interview, 02 Oktober.

Hadi, Syamsul, (2019). Judge of Sawahlunto Religious Court, Interview, 02 Oktober.

Law No. 1 of 1974 concerning marriage

Compilation of Islamic Law in 1991

http:/ / kamusbahasainggris.com/, Kamus

Bahasa Inggris Online accessed january 18, 2020. 